Journal of Engineering and Applied Sciences 6(1): 96-103, 2011

ISSN: 1816-949X

(C) Medwell Journals, 2011

\title{
Matrix Converter Power Quality Issues Compensation Using Unified Power Quality Conditioner
}

\author{
P. Jeno Paul, I. Jacob Raglend and T. Ruban Deva Prakash \\ Department of Electrical and Electronics Engineering, Noorul Islam University, Tamilnadu, India
}

\begin{abstract}
This study proposes a Unified Power Quality Conditioner (UPQC) to minimize the power quality impact present in the matrix converter's instead of passive filter. A matrix converter produces significant harmonics and nonstandard frequency components into load. The proposed approach eliminates the total harmonic distortion efficiently and also mitigates sag swell present in matrix converter's load voltage. The smaller THD, the harmonic pollution in the power system will be reduced and the power quality will be increased. The proposed approach has been tested and validated on the matrix converter using MATLAB/ Simulink software. The simulation results are shown to demonstrate the advantages of the proposed scheme.
\end{abstract}

Key words: Matrixconverter, unified power quality conditioner, power quality, voltage harmonics, voltage sag and swell, India

\section{NTRODUCTION}

The matrix converter is the three phases to three phase configuration with direct $\mathrm{AC}-\mathrm{AC}$ converter topologies (Wheeler et al., 2008), the matrix converter has several advantages over traditional rectifier-inverter type power frequency converters. It provides sinusoidal input and output waveforms. It has inherent bi-directional energy flow capability the input power factor can be fully controlled. Finally, it has minimal energy storage requirements which allows to get rid of bulky and lifetimelimited energy-storing capacitors. In spite of the advantages, the matrix converter has also some disadvantages. It has a maximum input output voltage transfer ratio limited to $\cong 87 \%$ for sinusoidal input and output waveforms. It requires more semiconductor devices than a conventional AC-AC indirect power frequency converter since, no monolithic bi-directional switches exist and consequently discrete unidirectional devices, variously arranged, have to be used for each bi-directional switch and particularly produces higher order harmonics (Yacamini and Oliveira, 1978).

The matrix converter consists of 9 bi-directional switches Thatallow any output phase to be connected to any input phase. The general architecture of matrix is shown in Fig. 1. Nine bi-directional switches the matrix converter can theoretically assume $512\left(2^{9}\right)$ different switching states combinations. However, not all of them can be usefully employed. Regardless to the control method used, the choice of the matrix converter switching

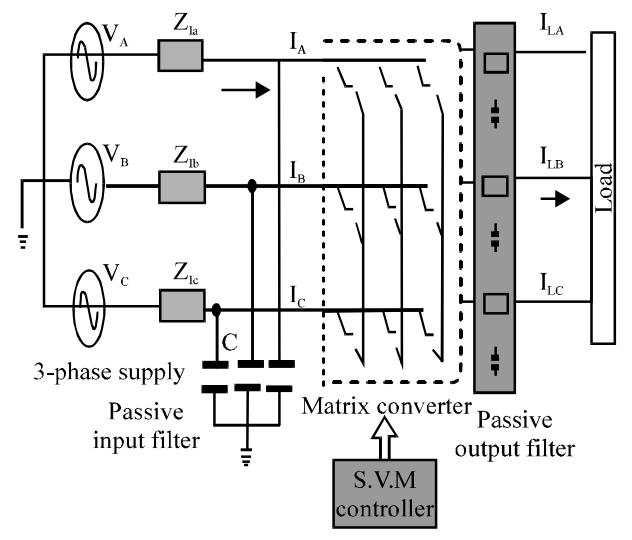

Fig. 1: General architecture of matrix converter

states combinations (from now on simply matrix converter configurations) to be used must comply with two basic rules. Taking into account that the converter is supplied by a voltage source and usually feeds an inductive load, the input phases should never be short-circuited and the output currents should not be interrupted. From a practical point of view these rules imply that one and only one bi-directional switch per output phase must be switched on at any instant. By this constraint in a three phase to three phase matrix converter only 27 switching combinations are permitted. The conventional compensation of harmonic reduction in the matrix converter is achieved by adding input parallel passive filters and series filters. But these filters are not working well when the supply frequency varies.

Corresponding Author: P. Jeno Paul, Department of Electrical and Electronics Engineering, Noorul Islam University, Tamilnadu, India 


\section{MATERIALS AND METHODS}

Power quality issues in matrix converter: Generally power quality is the set of limits or conditions of electrical properties that allows electrical devices to function in their planned manner without loss of performance. Without the proper power an electrical utility or load may malfunction, fail permanently or not operate at well. Ideally, voltage is fed by a utility as sinusoidal having a magnitude and frequency given by international standards or system specifications with an impedance of zero ohms at all frequencies. Generally electrical power source is ideal and it can deviate in the following ways. Variations in the peak or RMS voltage are important to different types of equipment and load. When the RMS voltage increases beyond the nominal voltage by $10-80 \%$ for 0.5 cycles to $1 \mathrm{~min}$, the phenomena is called a swell (Kusko and Marc, 2007).

Sag is the opposite action. The RMS voltage is below the rated voltage by $10-90 \%$ for 0.5 cycles to $1 \mathrm{~min}$ (Fuchs and Mosoum, 2008). Variations in the wave shape are usually known as harmonics (Heydt, 1995). Over voltage occurs when the nominal voltage increases above $110 \%$ for $>1 \mathrm{~min}$. (Chandrasekaran et al., 2009). Under voltage occurs when the nominal voltage fall or below $90 \%$ for $>1 \mathrm{~min}$ (Heydt, 1995). The input voltage directly reflects the output voltages of matrix converter (Wheeler et al., 1993). Sag swell over voltage and under voltage are occurs in the input voltage and with to the reference to above factors the output voltage of the matrix converter also distorts. Next is the important harmonic source is $\mathrm{Ac} / \mathrm{DC}$ converters/inverters and $\mathrm{AC} / \mathrm{Ac}$ converter like matrix converter. Many low-power singlephase converters/ inverters and high-power three phase converters/inverters are being used in electrical power systems.

Harmonic is defined as a sinusoidal component of a periodic wave having a frequency that is an integral multiple of the fundamental frequency (Karaca and Akkaya, 2009). In matrix converter two types of harmonics such as voltage harmonics are produced and is given in Eq. 1 and 2:

$$
\begin{aligned}
& \text { For voltage: } \mathrm{THD} v=100 \sqrt{\frac{v_{\mathrm{h}}^{2}}{v_{1}}} \\
& \text { For current: THDi }=100 \sqrt{\frac{\mathrm{i}_{\mathrm{h}}^{2}}{\mathrm{I}_{1}}}
\end{aligned}
$$

Where, $i_{h}$ and $v_{h}$ are current and voltage harmonics, respectively. There are many nonlinear loads drawing non sinusoidal currents from electrical power systems. These no sinusoidal currents pass through different impedances in the power systems and produce voltage harmonics. These voltage harmonics propagate in power systems and affect all of the power system components. Most of the other electrical loads are sensitive to harmonics. Matrix converters produce harmonics.

This harmonics may lead to their improper operation. Passing harmonic currents through the utility lines cause interference with the communication circuits near the transmission lines and may cause a malfunction in these circuits.

On the other hand, harmonics cause disturbance in sensitive loads in power systems such as sensitive medical devices, control circuits and computers (De la Rosa, 2006). Control circuits that researchers on current or voltage zero crossing have higher sensitivity to harmonics and may not work properly in the presence of harmonics.

The proposed UPQC based compensation scheme for matrix converter: The Unified Power Quality Conditioner (UPQC) is a versatile device which could function as series active filter and shunt active filter. UPQC can simultaneously fulfill different objectives like, maintaining a balanced sinusoidal (harmonic free) nominal voltage at the load, eliminating harmonics in the source currents, load balancing and power factor correction. In the 3-phase 3 wire, UPQC system consists of the converter VSCl, input filter inductance $\mathrm{L}_{1}-\mathrm{L}_{3}$, input filter capacitor $\mathrm{C}_{11}-\mathrm{C}_{13}$, DC-link capacitor CDC, the converter VSC2, output filter inductance $\mathrm{L}_{4}-\mathrm{L}_{6}$, output filter capacitor $\mathrm{C}_{21}-\mathrm{C}_{23}$, series transformer $\left(\mathrm{T}_{\mathrm{A}}-\mathrm{T}_{\mathrm{C}}\right.$ ), load and so on (Fig. 2).

The converter VSCl outputs voltage $\mathrm{V}(\mathrm{a}-\mathrm{c})$ between source voltage $\mathrm{Vs}_{(\mathrm{a}-\mathrm{c})}$ and load voltage $\mathrm{VL}_{(\mathrm{a}-\mathrm{c})}$ through inductance $\mathrm{L}_{1}$ and transformer $\mathrm{Ts}$ which is called series converter. The converter VSC2 outputs compensated current $I_{(a-c)}$ between source current Is (a-c) and load current $\mathbb{L}$ (a-c) through filter inductance $\mathrm{L}_{(1-3)}$ and filter capacitor $\mathrm{C}_{(1-3)}$ which is called parallel converter (Jenopaul et al., 2010a, b). It can be seen that the series converter and the parallel shown in Fig. 2. The series active filter compensates all types of voltage harmonics (Jenopaul et al., 2010a, b). Space vector modulation control is used to control the matrix converter.

Modeling and analysis of UPQC-matrix converter: Figure 3 shown the fundamental representation of UPQC with matrix converter. UPQC is a combination of a shunt and a series compensator cascaded via a DC link capacitor which facilitates the sharing of the active power between the two. Shunt active filter of the UPQC is modeled as a controlled current source and the series active filter is 




Fig. 2: Proposed UPQC based compensation for matrix converter

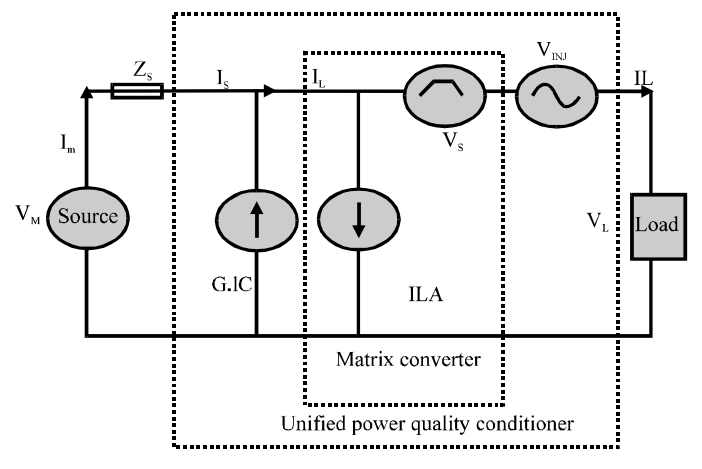

Fig. 3: Fundamental representation of UPQC with matrix converter

modeled as a controlled voltage source. Bus voltage Vm is taken as the source. The supply generator side voltage is represented as $V_{M}$. $I_{M}$ is the source current. $V_{P C C}$ is the intermediate bus voltage and $V_{\text {inj }}$ is the voltage injected by the series active filter of the UPQC. The supply side voltage is in phase with the PCC voltage. $I_{S}$ is the supply current which is in anti-phase with the load side voltage. $I_{C}$ is the current injected from the shunt active filter of the UPQC.

The load terminal voltage is represented as $V_{L} . I_{L}$ is the load current. The dynamics of the DC link capacitor is ignored in the modeling of the UPQC. This has been done on the assumption that the DC link capacitor voltage stays constant all the time. Series active filter compensates the harmonic voltage source and it is placed in between the matrix converter and load. If the series active filter is controlled as:

$$
\mathrm{V}_{\mathrm{inj}}=\mathrm{KGI}_{\mathrm{S}}
$$

In Eq. 3, $\mathrm{v}_{\text {inj }}$ is the series active filter is is the source current. $G$ is equivalent transfer function. The source current is:

$$
I_{S}=\frac{v_{S}-v_{L}}{z_{S}+z_{L}+k G}
$$

Where:

$\mathrm{Zs}=$ The source (line) impedance

$I_{L}=$ The equivalent harmonic current source

$Z_{L}=$ The equivalent impedance on the input side of matrix converter which may include passive filters and power factor correction capacitors

$\mathrm{G}=$ The equivalent transfer function of the active filter including the detection circuit of harmonics and the delay of the control circuit

$\mathrm{K}>>1$ purequirese operating condition for the series active filter to compensate for a harmonic source. In general, $G$ has the function of notching the fundamental component that is $|\mathrm{G}|_{\mathrm{h}}=\mathrm{O}$ at the fundamental and $|\mathrm{G}|_{\mathrm{h}}=$ 1 for harmonics. All equations are represented in per unit. From Fig. 3, the following equations are obtained for shunt part of UPQC:

$$
\begin{gathered}
I_{C}=G_{L} \\
I_{s}=\frac{Z_{L}}{Z_{s}+\frac{Z_{L}}{1-G}}, I_{L O}+\frac{V s}{Z_{s}+\frac{Z_{L}}{1-G}} \\
I_{L}=\frac{\frac{Z_{L}}{1-G}}{Z_{s}+\frac{Z_{L}}{1-G}}, I_{L O}+\frac{1}{1-G}, \frac{V s}{Z_{s}+\frac{Z_{L}}{1-G}}
\end{gathered}
$$

Focusing on harmonic: 


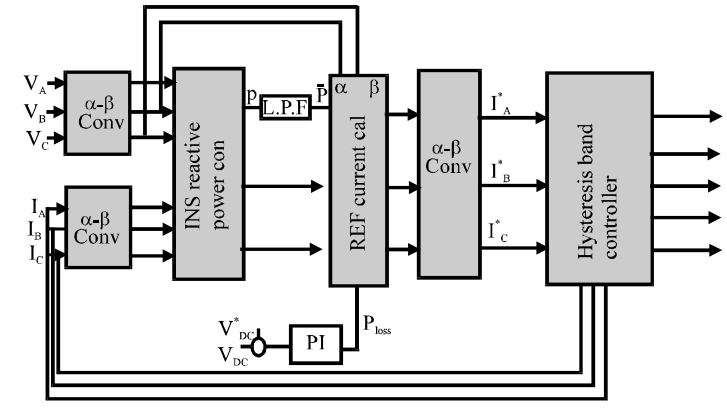

Fig. 4: Control system design of shunt active power filter for matrix converter

$$
\begin{gathered}
\left|\frac{\mathrm{z}_{\mathrm{L}}}{1-\mathrm{G}}\right|_{\mathrm{h}}>\left|\mathrm{Z}_{\mathrm{s}}\right|_{\mathrm{h}} \\
\mathrm{I}_{\mathrm{C}}=\mathrm{I}_{\mathrm{Lh}} \\
\mathrm{I}_{\mathrm{Lh}}=\mathrm{I}_{\mathrm{LOh}}+\frac{\mathrm{V}_{\mathrm{sh}}}{\mathrm{Z}_{\mathrm{L}}}
\end{gathered}
$$

Where, the subscripts $h$ and $f$ represent the harmonic components and the fundamental components, respectively. Modulus represents the magnitude of a transfer function. $G$ can be predesigned and determined by the active filter while $\mathrm{Zs}$ and $\mathrm{Z}_{\mathrm{L}}$ are determined by the system, i.e., parameters of the ac source and the load side of the matrix converter. The control objective to be achieved during the normal working condition is that the shunt active filter of the UPQC must provide the reactive power required by the generator, connecting transformer or any other inductive device. During any abnormal condition, the series active filter of the UPQC should regulate the incoming voltage and compensate for any voltage sag or swell and the shunt active filter should continue to provide the reactive power and at the same time, it should maintain the DC link capacitor voltage at a constant value.

Analysis and the coordination control scheme of shunt active filter: Figure 4 shows the proposed compensation for matrix converter with a shunt active filter, source and load when the filter is used to compensate the current harmonics produced by the matrix converter. Active filter compensates the harmonic current of a matrix converter which produces harmonic current. In Fig. 3, ZsA-ZsC is impedances of the source and shunt passive filter, respectively. $\mathrm{I}_{\mathrm{Lh}}, \mathrm{V}_{\mathrm{Lh}}$ and $\mathrm{V}_{\mathrm{sh}}$ are the current harmonic of the load and voltage harmonic of the load and source harmonics, respectively. IAF is the current of the shunt active filter. Shunt active filters are used to compensate current harmonics of nonlinear loads to perform reactive power compensation and to balance imbalance currents. A shunt active filter senses the load current and injects a current into the system to compensate current harmonics or reactive load. In this study, a shunt filter was used to compensate the current harmonics of matrix converter here the shunt active filter acts as a current source. The sum of its current and load current is the total current that flows through the source. Therefore, controlling the output current of the active filter can control the source current. The shunt active power filter control algorithm is shown in Fig. 4. Instantaneous reactive power (p-q) theory is used to control of shunt active power filter in real time. In this theory, instantaneous 3-phase current and voltages are transformed to $\alpha-\beta-0$ from a-c coordinates as shown in Eq. 11 and 12:

$$
\begin{aligned}
& {\left[\begin{array}{l}
v_{0} \\
v_{\alpha} \\
v_{s}
\end{array}\right]=\sqrt{\frac{2}{3}}\left[\begin{array}{ccc}
\frac{1}{\sqrt{2}} & \frac{1}{\sqrt{2}} & \frac{1}{\sqrt{2}} \\
1 & -\frac{1}{2} & \frac{1}{\sqrt{2}} \\
0 & \frac{\sqrt{3}}{2} & -\frac{\sqrt{3}}{2}
\end{array}\right]\left[\begin{array}{l}
v_{\mathrm{sa}} \\
v_{\mathrm{sb}} \\
v_{\mathrm{sc}}
\end{array}\right]} \\
& {\left[\begin{array}{l}
i_{0} \\
i_{\alpha} \\
i_{\beta}
\end{array}\right]=\sqrt{\frac{2}{3}}\left[\begin{array}{ccc}
\frac{1}{\sqrt{2}} & \frac{1}{\sqrt{2}} & \frac{1}{\sqrt{2}} \\
1 & -\frac{1}{2} & \frac{1}{\sqrt{2}} \\
0 & \frac{\sqrt{3}}{2} & -\frac{\sqrt{3}}{2}
\end{array}\right]\left[\begin{array}{l}
i_{\mathrm{sa}} \\
i_{\mathrm{sb}} \\
i_{\mathrm{sc}}
\end{array}\right]}
\end{aligned}
$$

Load side instantaneous real and imaginary power components are calculated by using source currents and phase-neutral voltages as shown in Eq. 12:

$$
\left[\begin{array}{c}
\mathrm{p}_{0} \\
\mathrm{p} \\
\mathrm{q}
\end{array}\right]=\sqrt{\frac{2}{3}}\left[\begin{array}{ccc}
v_{0} & 0 & 0 \\
0 & v_{\alpha} & v_{\beta} \\
0 & -v_{\alpha} & v_{\beta}
\end{array}\right]\left[\begin{array}{l}
i_{0} \\
i_{\alpha} \\
i_{\beta}
\end{array}\right]
$$

Instantaneous real and imaginary powers include $\mathrm{AC}$ and DC components as shown in Eq. 13. DC components of $\mathrm{p}$ and $\mathrm{q}$ composed from positive sequence components ( $p$ and $q$ ) of load current. AC components ( $\tilde{p}$ and $\tilde{q}$ ) of $p$ and $\mathrm{q}$ include harmonic and negative sequence components of load currents. In order to reduce neutral current $\mathrm{p}_{0}$ was calculated by using $\mathrm{DC}$ and $\mathrm{AC}$ components of imaginary power and the $\mathrm{AC}$ component of real power as shown in Eq. 14 if both harmonic and reactive power compensation is required:

$$
\mathrm{p}_{0}=v_{0}, \mathrm{i}_{0}: \mathrm{p}=\overline{\mathrm{p}}+\tilde{\mathrm{p}}: \mathrm{q}=\overline{\mathrm{q}}+\tilde{\mathrm{q}}
$$




$$
\left[\begin{array}{l}
i_{s \alpha}^{*} \\
i_{s \beta}^{*}
\end{array}\right]=\frac{1}{v_{\alpha}^{2}+v_{\beta}^{2}}\left[\begin{array}{cc}
v_{\alpha} & -v_{\beta} \\
v_{s} & v_{\alpha}
\end{array}\right]\left[\begin{array}{c}
\bar{p}+p_{0}+\tilde{p}_{\text {loss }} \\
0
\end{array}\right]
$$

Where, $I_{s \alpha}^{*}$ and $I_{s \beta}^{*}$ reference currents of shunt active power filter in $\alpha-\beta-0$ coordinates. To compensate neutral current $i^{*}, s_{0}=-i_{0}$. These currents are transformed to 3-phase system as shown in Eq. 16:

$$
\left[\begin{array}{l}
\dot{i}_{s \mathrm{~s}}^{*} \\
\dot{i}_{\mathrm{sb}}^{*} \\
\dot{i}_{\mathrm{sc}}^{*}
\end{array}\right]=\sqrt{\frac{2}{3}}\left[\begin{array}{ccc}
\frac{1}{\sqrt{2}} & 1 & 0 \\
\frac{1}{\sqrt{2}} & -\frac{1}{2} & \frac{\sqrt{3}}{2} \\
\frac{1}{\sqrt{2}} & -\frac{1}{2} & -\frac{\sqrt{3}}{2}
\end{array}\right]\left[\begin{array}{l}
i_{\mathrm{so}}^{*} \\
i_{\mathrm{s} \alpha}^{*} \\
i_{\mathrm{s \beta}}^{*}
\end{array}\right]
$$

The reference currents in 3-phase system $\left(\mathrm{i}^{*}{ }_{\mathrm{sa}} \mathrm{i}_{\mathrm{sb}}\right.$ and $i^{*}{ }_{s c}$ ) are calculated in order to compensate neutral, harmonic and reactive currents in the load. The switching signals used in shunt active power filter control algorithm are generated by comparing reference currents and actual line currents using hysteresis band current control algorithm.

Dc link voltage stabilization control system: The overall power balance of the UPQC is maintained through the DC-link capacitor. When voltage sag is addressed by the series active power filter, the real power proportional to the voltage injected is absorbed by the DC-link. The DC-link voltage controller of the shunt active power filter in case of UPQC mode of operation ensures that this power is injected back into the power system thereby maintaining a constant DC-link voltage. Therefore, overall real power absorbed or injected by the UPQC is null. The DC-link controller shown in Fig. 4.

Analysis and the coordination control scheme of series active filter: Series active filters can be single-phase or 3 -phase, voltage source or current source converter. It is a part of unified power quality conditioner. A series active filter is used to eliminate the voltage harmonics produced by the matrix converter. When the load is sensitive and critical, a series converter is used to regulate line voltage for the load. It cancels out any line voltage distortions such as voltage harmonics, sag, swell and voltage unbalance. It is capable of eliminating any voltage harmonics with a frequency within the bandwidth of the control scheme.

For voltage sag (swell) compensation, active power must be delivered to (received from) the system. This active power is supplied (received) by the DC capacitor and creates a voltage ripple on the $\mathrm{DC}$ bus voltage. The second function of the series converter of UPQC which is mostly considered in very high-power applications is defined to protect the power system against the voltage distortions originating from the load. Some nonlinear loads which usually have a capacitor bank after a bridge rectifier appear to be voltage harmonic generators. The voltage harmonics at the Point of Common Coupling (PCC) affect the other sensitive loads connected to this point. The series converter is capable of suppressing the voltage harmonics of the load.

The main disadvantage of matrix converter is if the input voltage distortions directly affect the output voltage. The series converter deals with the input voltage distortions. It injects or receives active power for voltage sag or swell compensation. It also delivers a zero average instantaneous power for voltage harmonic cancelation. The voltage across the series converter is:

$$
\mathrm{V}_{\mathrm{f}}=\mathrm{V}_{\mathrm{ref}}-\mathrm{V}_{\mathrm{s}}+\sum \mathrm{V}_{\mathrm{h}}=\mathrm{V}_{\mathrm{s}}(1-1 / \mathrm{k})+\sum \mathrm{V}_{\mathrm{k}}
$$

In Eq. $17 \mathrm{k}=\mathrm{Vs} / \mathrm{V}_{\text {ref }}$ and $\mathrm{V}_{\mathrm{h}}$ is the voltage harmonic of the source. All the voltages are instantaneous values. Considering only active current through the line, the characteristic power of each phase of the series converter is:

$$
\mathrm{CS}_{\text {series }}=v_{\mathrm{s}} \mathrm{I}_{1} \cos \theta \sqrt{\left(\frac{1}{\mathrm{k}}-1\right)^{2}}+\mathrm{THD}_{\mathrm{v}}{ }^{2}
$$

Where, THDv is the Total Harmonic Distortion (THD) of the source voltage and is defined as:

$$
\mathrm{THD} v=\sqrt{\sum v_{\mathrm{h}}^{2} / \mathrm{Vs}}
$$

$\operatorname{Cos} \theta$ is the power factor of the load and $I_{L}$ is the fundamental component of the load current. A series active filter senses the load voltage and injects the compensated voltages into the system to compensate

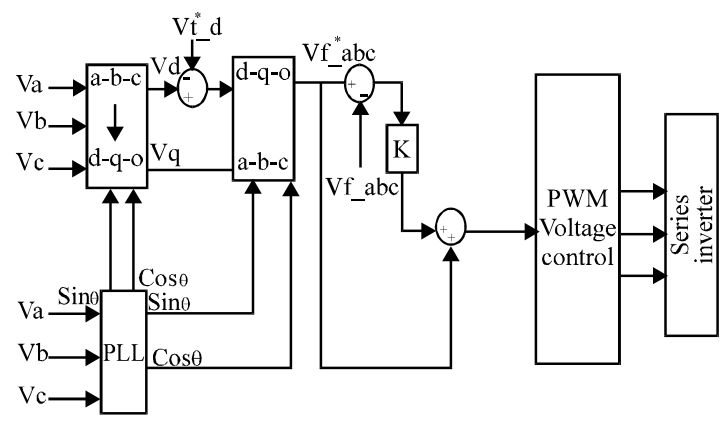

Fig. 5: Control system design of UPQC (series active power filter) for matrix converter 
voltage harmonics. In this study, a series active filter used to compensate the voltage harmonics of matrix converter. Matrix converter is sensitive to the disturbances of the input voltage. The series active filter also compensates the imbalance voltage present in the output voltage and is compensated. Figure 5 shows the series active filter controlling block diagram using synchronous reference frame theory. In this method, the desired value of load phase voltages in $d$ axis and $q$ axis is compared with the load voltage and the result is considered as the reference signal. The supply voltage detected $\left(\mathrm{V}_{\mathrm{abc}}\right)$ is detected and transformed into the synchronous dqo reference frame using:

$$
v_{t_{-} d q 0}=\mathrm{T}_{a b c}^{\mathrm{dqo}} v_{\mathrm{t}_{-} \mathrm{abc}}
$$

The compensating reference voltage in the synchronous dqo reference frame is defined as:

$$
v_{\mathrm{sf}-\mathrm{dqo}}^{\mathrm{ref}}=v_{\mathrm{t}_{-} \mathrm{dqo}}-v_{1_{-} \mathrm{dqo}}^{\text {exp }}
$$

The compensating reference voltage in Eq. 21 is then transformed back into the (a_b_c) reference frame. Resulted reference voltage $\left(v_{\mathrm{fa}}^{*}, v_{\mathrm{i}} \mathrm{f}_{\mathrm{fb}}, v_{\mathrm{fc}}^{*}\right)$ and the output current of shunt inverter $\left(v_{\mathrm{fa}}, v_{\mathrm{fb}}, v_{\mathrm{fc}}\right)$ are fed to the hysteresis band controller. The required controlling pulses are generated and the required compensation voltage is generated.

\section{RESULTS AND DISCUSSION}

The simulations with MATLAB/SUMLINK were performed for the purpose of analyzing the operation of the proposed system. The power circuit is modeled as a 3-phase 4 wire system. The circuit parameters that were used are shown in Table 1. In the simulation studies, the resultt are specified before and after UPQC system is operated. In Fig. 6, the simulations of the matrix converter operates without input capacitor is shown. Here, the line voltage is $440 \mathrm{v}$; the supply current is 200 Amperes. In

Table 1: The cricit parameters value

\begin{tabular}{llll}
\hline Source & Voltage & VSabc & $510 \mathrm{~V}_{\text {ms }}$ \\
\hline \multirow{2}{*}{ Load } & Frequency & $\mathrm{F}$ & $50 \mathrm{~Hz}$ \\
DC link & 3 phase load resistance & $\mathrm{R}_{\mathrm{L}}$ & $2 \Omega$ \\
& Voltage & $\mathrm{Vdc}$ & $900 \mathrm{~V}$ \\
Series Active & Capacitor & $\mathrm{C}_{1}, \mathrm{c}_{2}$ & $2200 \mu \mathrm{F}$ \\
Power Filter & Filine inductance & $\mathrm{LCabc}$ & $0.5 \mathrm{mH}$ \\
& Filter capacitor & RCabc & $2 \Omega$ \\
& Switching frequency & CCabc & $100 \mu \mathrm{F}$ \\
Shunt & Ac line inductance & Fpwm & $20 \mathrm{KHz}$ \\
active filter & Filter resistance & LCabc & $5 \mathrm{mH}$ \\
& Filter capacitor & RCabc & $2 \Omega$ \\
& Switching frequency & CCabc & $100 \mu \mathrm{F}$ \\
& & Fpwm & $20 \mathrm{KHz}$ \\
\hline
\end{tabular}

this simulation, the input current wave shape is non sinusoidal and it contains harmonics. The simulation time start from 0.02-0.085 sec. Consider the simulation time $0.025-0.045 \mathrm{sec}$, search is the one cycle of the current waveform.

Here, the wave shape of this current is non sinusoidal and it contains harmonics. Figure 6 shows the UPQC based quality control scheme. Figure 7 a shows the input voltage is 520 volt frequency is $50 \mathrm{~Hz}$. Simulation start at $0-0.08 \mathrm{sec}$. The simulation result (Fig. 7a) shows the input voltage is harmonic free. Figure $7 \mathrm{~b}$ shows the
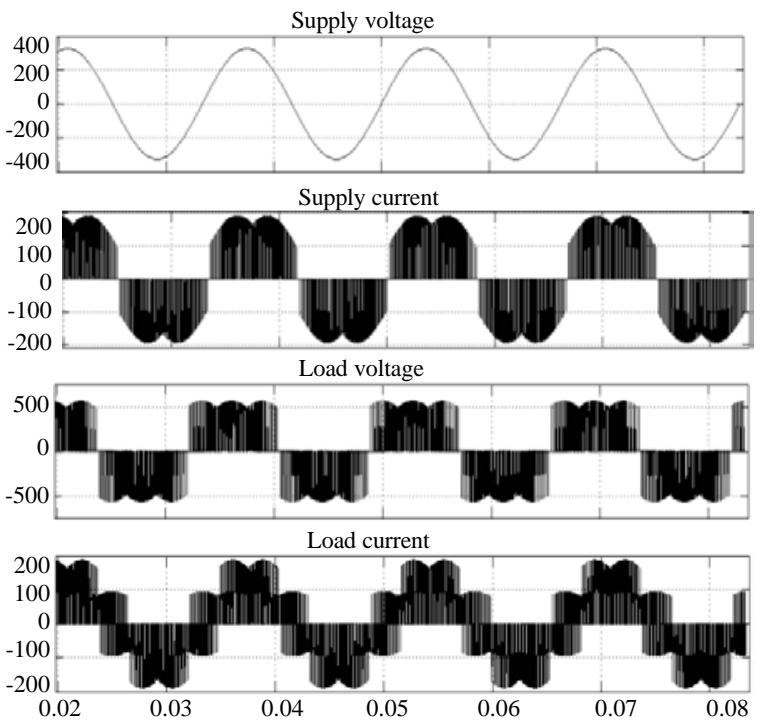

Fig. 6: System voltage (vS), source current (is) load voltage (VL) and load current (IL) without filter
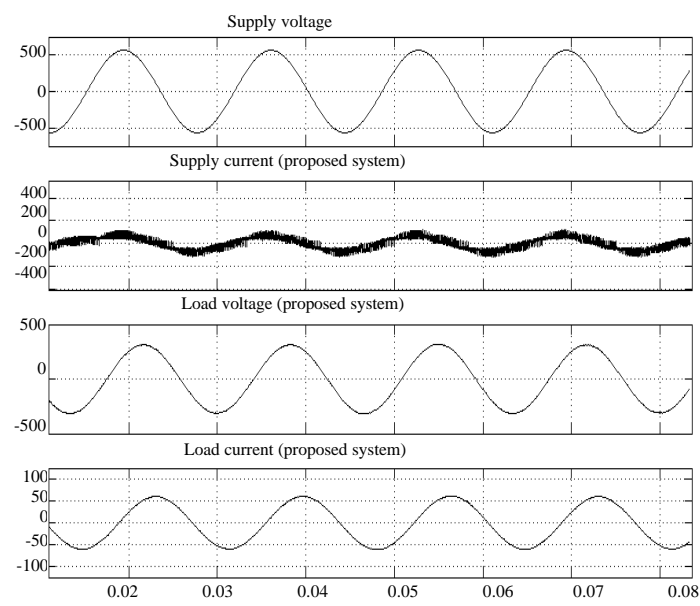

Fig. 7: a) Input supply voltage; b) supply current in proposed system; c) matrix converter output voltage voltage (proposed compensation) and d) load current compensation (proposed) 




Fig. 8: Matrix converter output voltage before compensation. (b) Input load current of shunt active filter

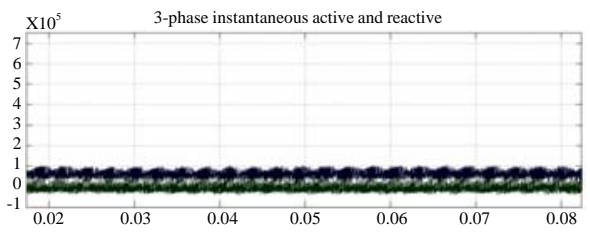

Fig. 9: Real and reactive compensation in UPQC based matrix converter
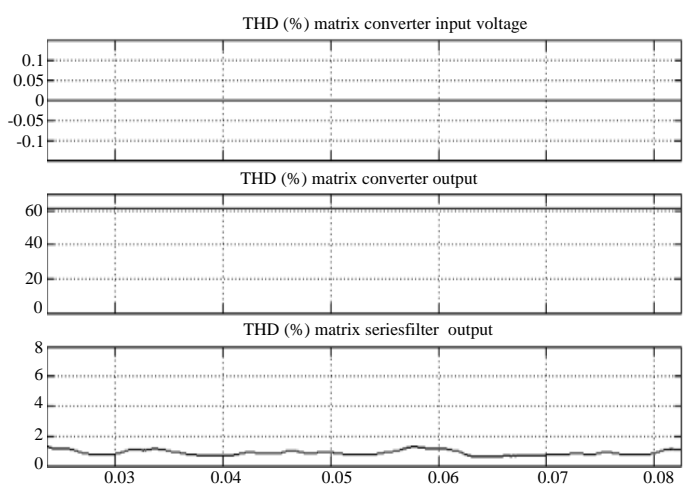

Fig. 10: a) Total harmonic distortion matrix converter input voltage; b) total harmonic distortion in matrix converter and c) total harmonic distortion in matrix converter output current

input current waveform of the matrix converter in a proposed control scheme. Figure $7 \mathrm{c}$ shows the load voltage proposed system applied. Figure $7 \mathrm{~d}$ shows the load current applied the proposed system. Here the load current is a resistive load. Figure 8 shows the matrix converter output voltage the simulation result shows the matrix output voltage contain harmonics. Figure $8 \mathrm{~b}$ shows the input current of series active filterpart. This simulations shows that the series active filter takes the current sinusoidal and the matrix converter voltage is 440 v. In Fig. 9, the real and reactive power maintained

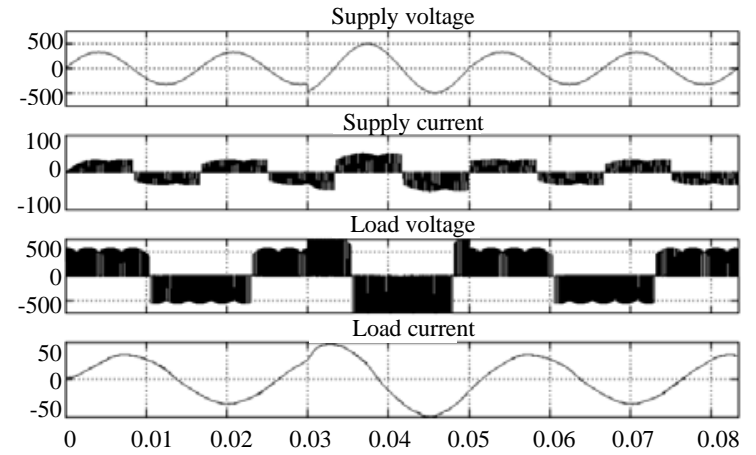

Fig. 11: a) Voltage swell according matrix converter; b) output current and c) voltage without compensation

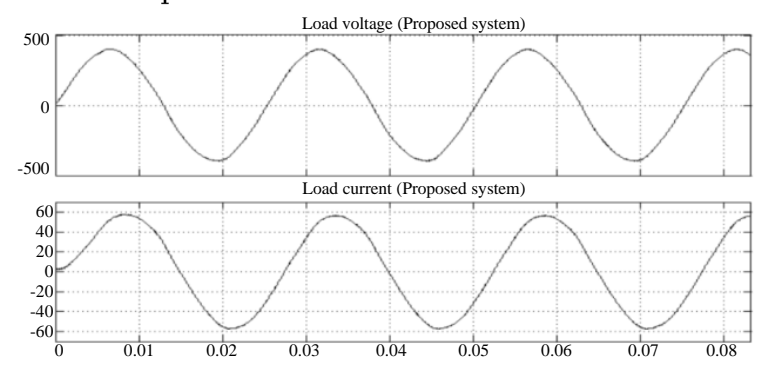

Fig. 12: a) Voltage swell accord in matrix converter and b) output current, voltage with compensation

constant as shown in the simulation result. Figure $10 \mathrm{a}$ shows the total harmonic distortion in the source voltage. There is no harmonic present. Figure 10b shows the total harmonic distortion in the matrix converter output. The matrix converter produced $60 \%$ of voltage harmonics shown in Fig. 10c, the THD reduced at $1 \%$ of proposed system. Figure 11a-c shows when the matrix converter is affected by swell. The voltage swell present at 0.03-0.05 sec. After the proposed compensation series active filter eliminates the swell problem and maintain the power quality in the matrix converter output as shown in the Fig. $12 \mathrm{a}, \mathrm{b}$.

\section{CONCLUSION}

This study proposed a unified power quality conditioner to compensate current and voltage variation and harmonic mitigation in matrix converter. The simulation results shows that when unbalance and nonlinear occur in load current or unbalance and sag in the source voltage, the proposed methodology eliminates the impact of distortion and unbalance of the load current on the power line, making the power factor to unity. Meanwhile, the series compensator isolates the loads voltages and source voltage, shunt compensator provide 3 -phase balanced and rated voltages of $\sin$ for loads. 


\section{REFERENCES}

Chandrasekaran, K., P.A. Vengkatachalam, M.N. Karsiti and K.S. Rama Rao, 2009. Mitigation of power quality disturbances. J. Theor. Applied Inform. Technol., 8: 105-116.

De la Rosa, F.C., 2006. Harmonics and Power Systems. Chapter 2, Taylor and Francis Group, New York, pp: 30 .

Fuchs, E. and M.A.S. Mosoum, 2008. Power Quality in Power Systems and Electrical Mechines. Academic Press Publication, USA., pp: 664.

Heydt, G.T., 1995. Electric Power Quality. 2nd Edn., Stars in a Circle Publications, Scottsdale, AZ USA., pp: 34.

Jenopaul, P., T.R.D. Prash and J.I. Regland, 2010a. Power quality improvement using series active filter for matrix converter controlled load. Int. J. Signal Syst. Control Eng. Appl., 3: 28-33.

Jenopaul, P., T.R.D. Prash, I.J. Regland and R.P. Darsini, 2010b. Power quality improvement for matrix converter using shunt active filter. Int. J. Comput. Applications, 11: $31-37$.
Karaca, H. and R. Akkaya, 2009. Control of venturini method based matrix converter in input voltage variations. Proceedings of the International Multi Conference of Engineers and Computer Scientists, March 18-20, Hong Kong, pp: 1-5.

Kusko, A. and M.T. Marc, 2007. Power Quality in Electrical System. Chapter 3. McGraw Hill, New York, pp: 7.

Wheeler, P.W., H. Zhang and D.A. Grant, 1993. A theoretical and practical investigation of switching frequency harmonics in a matrix converter. Proceedings of the Universities Power Electronics Conference, September 1993, Stafforf, UK., pp: 502-505.

Wheeler, P.W., P. Zanchetta, J.C. Clare, L. Empringham, M. Bland and D. Katsis, 2008. A utility power supply based on a four-output leg matrix converter. IEEE Trans. Ind. Appl., 44: 174-186.

Yacamini, R. and J.C. Oliveira, 1978. Harmonics produced by direct current converter transformers. Proc. Inst. Elect. Eng., 25: 873-878. 